\title{
HOW SOVIET COLD WAR POLICIES FELL PREY TO THE TEMPTATIONS OF STRATEGIC TRAPS ${ }^{\tau}$
}

\author{
SOVYET SOĞUK SAVAŞ POLITIKKALARI STRATEJİK TUZAKLARIN \\ AYARTMALARINA NASIL YENIK DÜŞTÜ
}

\author{
Gültekin SÜMER ${ }^{1}$
}

\begin{abstract}
The Cold War experience of the Soviet Union is a significant case study in terms contributing to the strategic thought. The Soviet strategic experience marked its place in history of strategic thought with its inability to strike the optimum between ideology and strategy. It indicated how a strategy under the yoke of an ideology may well impel a hegemonic power falling into strategic traps. The underlying cause of this fact was that the pre-eminence of ideological goals on the part of the Soviet regime would not allow a grand strategy to keep its coherence. Making Germany one of the indispensable elements of its strategic identity has made an effect of speeding up the process of falling into strategic traps. Furthermore, the Eastern European geography that it held as a strategic advantage ended up with its loss of the Cold War. By the CSCE process the East Bloc gained its own momentum by questioning the legitimacy of the Soviet Union in Eastern Europe. Falling well behind the requirements of a strategic notion in terms of both gaining freedom of manoeuvre and seeing the big picture correctly, it would not be astonishing at all on the part of the Soviet ideology not accomplishing its Cold War goals. In this study, open sources will be used in order to verify the main hypothesis as this is a history fact-finding research.
\end{abstract}

Key Words: Strategic Trap, Soviet Union, The Cold War, Europe, Strategy

$\ddot{\boldsymbol{O}} \boldsymbol{z}$

Sovyetler Birliği’nin Soğuk Savaş deneyimi stratejik düşünceye katkı sağlama bakımından önemli durum olay çalışmasıdır. Sovyet stratejik deneyiminin stratejik düşünce tarihinde yeri ideoloji ve strateji arasındaki optimumu bulamamasiyla yer etmiştir. Bu ideolojinin boyunduruğu altındaki bir stratejinin nasıl bir hegemonyacı gücü stratejik tuzaklara sevk edebileceğini göstermiştir. Bu gerçeğin altında yatan neden Sovyet rejiminin ideolojik hedeflerinin kendi iç uyumunu korumasına izin vermemesi olmuştur. Almanya'yı stratejik kimliğinin vazgeçilmez öğelerinden biri haline getirmek stratejik tuzaklara düşmesini hızlandırıcı etki yapmıştır. Dahası, stratejik bir avantaj olarak elinde tuttuğu Doğu Avrupa Soğuk Savaş’ı kaybetmesiyle sonuçlanmıştır. AGÍK süreciyle birlikte Doğu Bloku kendi momentumunu kazanarak Sovyetler Birliği'nin Doğu Avrupa'daki meşruiyetini sorgular hale

\footnotetext{
Makale Gönderim Tarihi: 18.10.2019

Makale Kabul Tarihi: 11.05.2020

${ }^{\tau} \mathrm{Bu}$ çalışmanın önemli bir kısmı British International History Group tarafından (BIHG) 30.08.-1.09.2018 tarihleri arasında Exeter Üniversitesi'nde düzenlenen otuzuncu yıllık konferansında bildiri olarak sunulmuştur. A large part of this study was presented at the thirtieth annual conference of the British International History Group (BIHG) held at the University Exeter on 30.08.-1.09.2018.

${ }^{1}$ Doç. Dr.; Beykent Üniversitesi Uluslararası İlişkiler Bölümü Öğretim Üyesi, gultekinsumer@beykent.edu.tr; ORCID iD: 0000-0001-8908-1115
} 
gelmiştir. Gerek manevra alanı kazanma gerekse de büyük resmi görme açısından stratejik nosyonun çok gerisinde kalan Sovyet ideolojisinin, Soğuk Savaş hedeflerini gerçekleştirememesi hiç de şaşırtıcı olmamuştır. Bu çalışma, bir tarih araştırması olduğu için, temel hipotezi doğrulamada açık kaynak taraması kullanılacaktır.

Anahtar Kelimeler: Stratejik Tuzak, Sovyetler Birliği, Soğuk Savaş, Avrupa, Strateji

\section{I.INTRODUCTION}

While there is no doubt that strategic gaps are undeniable facts of hegemonic state policies, certain dynamics render them vulnerable to falling into strategic traps. Strategic traps are peculiar to historical empires which attribute expansionism an existential meaning since no empire could ever shun expansionist policies. There is no doubt that Soviet Union was not any kind of actor that the history of strategic thought was quite familiar with its own notion of strategic thought. This very fact would turn into a question of strategic case worth examining. Soviet Union was one of the recent examples within the diplomatic history. Besides, the concept of strategic trap has not been broadly examined in the IR discipline in the context of hegemonic powers as it merits. Almost all the hegemonic powers fell prey into hegemonic traps and the.

In this study, I am intending to examine the strategic gaps of the Soviet Union and how they impelled it to strategic traps leading to its ultimate loss of the Cold War. First, the concept of strategic trap will be clarified with three concrete examples within the diplomatic history. Then, I am going to clarify the strategic identity of the Soviet Union in order to assess its strategic actions correctly. This is going to take me to find out why the Soviet Union could not harmonize its peculiar strategic identity with of the requirements of strategic theory as the first Marxist-Leninist hegemonic power in the diplomatic history. Besides, I am going dwell on how the quest for coherence in Soviet ideology or in 'Soviet civilization' played a preeminent role in drifting the Soviet Union into strategic traps. And dare to ask the crucial question: Was the main cause underlying Soviet Union's losing the Cold War pushing the limits of her 'grand strategy'?

It goes without saying that the Cold War was a section within the strategic history ushering in new strategic components which would render foreign and security policies much more vulnerable to the perils and the temptations of the strategic traps. I see the main cause in this fact the insertion ideological values into a grand strategy logic much more intensely.

In this study, open sources were used in order to verify the hypothesis as this is a history factfinding research. I am going to formulate the concept of strategic traps based on historical cases. Afterwards, I am going to put the Soviet strategic identity and try to see how it could adapt itself to the Cold War experiences.

There is no doubt that the Marxist-Leninist ideology was regarded by the Kremlin as the most valuable strategic asset in the hands of the Soviet regime in its strategic approach towards Europe. Being in the position of a revisionist side the main goal and the priority of the Soviet Union was to convert its post- Second World War territorial gains into strategic and ideological gains in the emerging European geopolitics. Nevertheless, while seeking to take the maximum efficiency from the power of the Marxist-Leninist ideology, the Soviet state could not help putting itself into an ideological conditioning which would make counterproductive effect of reducing both efficiency and effectiveness of its strategic actions. 
This fact has made the Soviet side much more vulnerable to falling prey to the temptations of strategic traps compared with the American side.

\section{II.THE LOGIC OF STRATEGIC TRAPS}

Strategic traps are one of the most common symptoms of offensive policies and strategies observed as a result of imperial overstretch ${ }^{2}$ throughout the diplomatic history. In the eyes of Paul Kennedy, the United States is the last example of this phenomenon since the sum total of the United States' global interests and obligations is far larger than the country's power to defend them all simultaneously (Kennedy,1989). Strategic traps are basically delusive opportunities that impel hegemonic powers to take erroneous strategic decisions in terms of keeping and promoting its interests. There is no doubt that strategic traps are by no means peculiar to hegemonic powers; nevertheless, it is the hegemonic states themselves that are mostly exposed to the enigmas of the strategic traps in their journeys throughout the diplomatic history. In practice, it is not easy for the hegemonic powers to exempt themselves falling into strategic traps. The most striking impact of the strategic traps over the foreign relations of the hegemonic powers is without any doubt undermining their strategic priorities. We can define strategic traps as the impasses that states get stuck in terms of identifying their priorities in their foreign and security policies and/or strategies. In the most common cases, there exists a strategic terrain or geography which is sufficiently tempting and enigmatic regarding the expansionist policies of a hegemonic actor.

Grand strategy is the art of finding the most possible optimum (or the correct nuance) among strategic components of an actors such as the strategic terrain, ideologic identity, leadership qualities, history, culture etc. In such a quest, states are supposed to determine their strategic priorities correctly in terms of reaching their strategic goals. What makes strategy a reality of art rather than a science is the delicate balance to be struck in terms of reaching strategic goals. In order to achieve this, every strategic actor has to perceive the big picture correctly and avoid the enticements that could easily drift her into traps.

The strategic performance of each actor is something that is measured with the adaptation capability she would demonstrate towards geography that she has stretched. This adaptation capability depends on the responses that they will give on the particular strategic terrain. Nevertheless, it is an inevitable truth that every strategic actor enters onto the strategic terrain with strategic gaps. Under these circumstances, eliminating or at least minimizing these gaps is the crucial side of a strategy that would gain a strategist his/her genuine value. Lawrence Freedman explains this fact as:

'Without some sense of where the journey should be leading it will be difficult to evaluate alternative outcomes. Like a grandmaster at chess, a gifted strategist will be able to see the future possibilities inherent in the next moves, and think through successive stages. '(Freedman,2013)

Definitely, one of the best examples of this practice was demonstrated by Hannibal at the battle of Caen during the Second Punic Wars between Rome and Carthage (Hart,1967) At this battle Hannibal skilfully exploited the strengths and weaknesses of his troops. He deployed has army so that the gradual retreat of his relatively weak Spanish and Gallic infantry drew

\footnotetext{
${ }^{2}$ The term overstretch was first coined by Liddell Hart, but was widely popularized by Paul Kennedy in his major works, Strategy and Diplomacy and The Rise and fall of the Great Powers.
} 
the Romans into his centre where they were trapped by more solid Libyan infantry on the flanks (Black,2008).

The history of warfare provides concrete cases in terms of understanding the causes of the strategic traps. When these cases are examined thoroughly, it will be seen that strategic traps stem mainly from three reasons. First, strategic traps may be the result of a concern to defend the coherence of a political ideology (or philosophy). In so far as holding a certain external territory under control occupies a crucial place in one state's political ideology, then such a state may be exposed to strategic traps. The very concern to protect the inner coherence of a political regime in this behaviour may impel an actor falling into strategic traps. The doctrine of the actor may involve very high standards of strategic concentration and therefore may impose her costs in finding the correct optimum. The Soviet experience as a case that is to be handled in this study is one of the best examples of this. Secondly, as a logic, strategic traps arise from the aggrandisement of foreign policy goals on behalf of a state actor. A state becomes much more open to strategic traps in so far as she gets stronger and expansion becomes the only alternative. A state might also overreact to the steps taken by her rival which might be perceived fatal to its interests. In so far as, a state raises its foreign policy goals and expectations, strategic gaps become gradually much more visible in that particular power's foreign policy. Under such circumstances, it is observed that such an actor whether political or military lacks the resources or cannot manage them effectively in order to prioritize its foreign policy goals. Serious disharmonies erupt in the formulation of the strategy intended. This is the case for most of the hegemonic journeys throughout the diplomatic history. It overwhelmingly manifests itself with 'overextension or overstretch' as the main symptom of this. As Kennedy states by the second half of the sixteenth century the empire was showing the signs of strategical overextension with a large army stationed in Central Europe an expensive navy operating in the Mediterranean, troops engaged in North Africa, the Aegean, Cyprus and the Red Sea, and reinforcements needed to hold the Crimea against a rising Russian power(Kennedy,1989). Thirdly, if territorial expansion is encouraged in a certain geography with the pressure of its increasing security concerns, states are more likely to be exposed to strategic traps. A commander and a political leader might be myopic in perceiving the existence of the strategic traps they are exposed to. Once an army or a state is exposed to strategic trap, it is highly unlikely to keep away themselves from this impasse, because it is imprisoned to the circumstances of the strategic terrain that was picked as a target. The expected cost-benefit equilibrium may well turn against the offensive side with the boomerang effect it makes. The seducing strategic terrain may impel them to take adventurous and risky decisions that could lead to disastrous consequences. As Snyder argues, even in some cases geography and technology may interact in shaping the incentives for expansionist strategies. For example, innovations in transportation technology, such as the building of the railroads in the colonial periphery in the 1890 s, may reduce the difficulty of projecting power in to the hinterlands and thus bring new territories and new strategic resources inside cost-benefit frontier of the empire (Snyder,1991). Furthermore, the geography may be a tough enough to put the actor's adaptation capability into difficulties. The strategic actor may realize that it has no choice than defeating and expanding. Even worse, it might not be possible on behalf of the hegemonic power to demonstrate a free will whether to stretch or not. The cause underlying this fact is that hegemonic powers do not feel 
themselves secure enough for their future well-beings. The costs of controlling a geography become gradually higher and higher in terms of strategic criterions. This evokes the crucial the question which would determine the fact of that particular strategic endeavour: Would the actor be able to keep the crucial optimum between offense and defence as soon as it is confronted with the potential strategic enticements on the terrain? To shed light on the concept of strategic trap, I have picked three striking examples in the diplomatic history. As mentioned above, throughout the diplomatic history, strategic traps have demonstrated themselves with the alluring geographies that hegemonic powers could not keep away themselves.

For sure Hitler's failure in 'Operation Barbarossa' was one of the typical examples of strategic traps in the history of the warfare. The Wehrmacht had entered the strategic terrain with a strategic gap. Hitler's hatred towards communism and his getting obsessed with capturing Stalingrad bearing Stalin's name had set the stage for Wehrmacht's getting into strategic trap. Having been exhausted by the war of attrition by the Soviet unprecedented resistance, both flanks of the $6^{\text {th }}$ army had been weakened and were bound to be attacked. The 'Operation Uranus' launched by General Zhukov would just target these flanks defended by Italian and Roman troops.

As for the imperial policies, one of the examples of strategic traps can be clearly seen in the expansionist policies of the Roman Empire with the dilemmas it was exposed to. The Roman Empire's eastward expansion invited harmful elements into the empire to its wellbeing. According to Gibbon, it was the natural and inevitable effect of immoderate greatness. The Prosperity ripened the principle of decay; the causes of destruction multiplied with the extent of conquest (Heather,2005). In the last years of his reign the Emperor Trajan suddenly fell upon Parthia (Henderson,1969). He was resolved to annex not only the vast country of Armenia, but also the Parthian dominions from the Syrian frontier to the Tigris and beyond. In A.D. 114, he added Armenia to the Roman Empire. In A.D. 116 he crossed the Tigris; stormed down the river past Baghdad; captured the Parthian capital Ctesiphon. Why did he break long peace with Parthia and attack? King of Parthia Chosroaes I appointed one of his nephew's Exedares to the throne of Armenia without consulting Trajan. Because no Roman army could advance securely through northern Mesopotamia with Armenia hostile and constantly threatening the left flank and the communications of column of march. The drain of men and money upon the resources of the entire Empire occasioned by Trajan's wars was terrifying. Trajan was too busy and too much occupied with his military enterprise to see fully that his expeditions were bringing the Empire to the verge of ruin. The cities of Italy and provinces were unable to bear the costs of series of wars which seemed inevitable. When Trajan died the position of the Roman Empire was extremely critical in terms of forestalling disintegration (Henderson,1969).

Chinese Civil War also offers a good example of strategic trap in a guerrilla warfare. In Chiang Kai-Shek's desire to seize Manchuria as a strategic asset. While Chiang's Kuomintang forces were intending to capture Manchuria in order to gain a strategic advantage against Eighth Route Army, that is forces loyal to Chinese Communist Party, they could not rescue themselves falling into the trap of overextending his supply lines and this made Kuomintang forces much more open to the counter attacks of the Eighth Route Army. By using this from 
this strategic trap as a leverage, the CCP forces managed to get the backing of the peasant population and capture the entire Manchuria at the end of 1948 (Taylor,2009).

\section{III.THE SOVIET UNION AS A STRATEGIC ACTOR}

What would determine the might and the success of a strategic doctrine is definitely its adaptation capability to the changing circumstances, say a certain geography, because the success of a strategy depends on the extent of the adaptation it will demonstrate towards the strategic terrain. When success becomes a question of adaptation, this certainly turns any strategic doctrine into a coherent formulation awaiting to be matched among constant factors $^{3}$ of grand strategy. If the strategy was the reflection and manifest of the Soviet identity, would it be successful in terms of adapting to the strategic terrain? And how would such a strategic move or positioning affect the inner balance of the Soviet Union?

For sure if any kind of ideological dimension is to be inserted in a grand strategy, then that particular grand strategy would take on much more delicate equilibrium. And the Soviet Union would demonstrate one of the best examples of this probe. Following her Second World War victory, Soviet Union was taking to the stage on behalf of feasibility of a grand strategy in which the achievement of ideological goals would determine the achievement of the strategy.

There is no doubt that Soviet Union was far from being an actor that the international order was quite familiar with. As the first Bolshevik hegemon in the history of great powers, the Soviet Union itself had created a reality of its own in terms of adapting herself to the emerging international order in the post-Second World War Europe. And the success in this reality would depend on the correct harmony among the constant factors. The Soviet Union was an actor whose existential future and position in the international order would depend on the harmony among several identical, ideological and geopolitical constants peculiar to the Soviet Union.

Corollary to this, its destiny was tied to simultaneous collaboration of various factors with each other. Since the Soviet Union had to keep its ideological existence and further its interests, this equalled to maintaining her ideological and strategic rivalry with the United States. By keeping the appeal of Marxism-Leninism vivid and disseminating it in the European continent, Soviet Union would establish the first communist society. By surpassing the capitalist West in terms of living standards, she would compete with her major rival United States in the arms technology (at least not fall behind), would maintain and strengthen her organic link with Eastern Europe and would not lose the strategic balance in Europe. Besides the coexistence of 15 Soviet republics would be a model of peace and prosperity for the future of mankind which would stress its supra-national identity. As a result of all these, its appeal as a new political model would hit the ceiling in the developing world.

Yet there is no doubt that such an unprecedented task would mean a huge burden in terms of its stability. Soviet Union was a political entity that involved much higher standards than a classical empire in order to keep its inner coherence. How to protect the empire against threats coming from the periphery that could harm the stability of the 'empire'? The Soviet Union had risen as a hegemon by leaning itself on such a delicate balance. With those peculiarities,

\footnotetext{
3 "Constant factors" is the term used by Sun Tzu in the Art of War
} 
Soviet Union would become one of the best bicycles examples ever to be found for political entities. The Soviet strategy would be shaped within the restraints set by the realities of the Soviet regime. And that was the essence of the Soviet strategic code. As long as the destiny of the Soviet Union was based on such a delicate balance, it was inevitable that she would face priority problems in terms of determining her strategic goals. Under such circumstances, the crucial task on behalf of the Soviet regime was to discern the main threat from the enticing ones, in order to see the big picture correctly. Briefly, in terms of the fate of the Soviet Union the question was how the Soviet regime would turn her ideological goals into strategic achievements, towards the pivotal European political geography in particular. For that, the harmony between ideology and strategy would be crucial which would determine the success of a Soviet foreign policy strategy.

Yet, there was no doubt that such a unprecedented revisionist positioning towards Europe would impose a huge burden on her both ideological and strategic goals. It would remain to be seen how such an ideology-strategy harmony would be achieved in the absence of any precedence. Would an effective strategy pave the way for the achievement of MarxistLeninist goals or vice versa? Would Moscow be able to see the big picture correctly? While ideology is by no means an obstacle in the accomplishment of the strategic goals, states could reach their goals in so far as their ideological identities could be incorporated into the cardinal rules of a strategic notion.

\section{III.THE CONSTANTS OF THE SOVIET REGIME}

No doubt the greatest strategic challenge for the Soviet Union in terms of such an adaptation was turning her strategic gains at the end of the Second World War into ideological gains and vice versa. There is no doubt that what would determine the future and the fate of Soviet strategic success in the Cold War was embedded within the Marxist-Leninist doctrine of the Soviet Union. In the absence of any precedent by any communist state, the foreign policy of the Soviet regime was in the position of being much more vulnerable to trial and error cases.

It was a fact that the Soviet regime had entered the Cold War under the restraints of ideological and historical determinants. Before all, Soviet foreign policy was under the ideological guidance of the Marxist-Leninist doctrine which the Soviet strategy owed its legitimacy. For Stalin responding to 'capitalist encirclement' with communist encirclement was a question of legitimacy question before a strategic one. He argued this in his work Voprosy Leninizma ${ }^{4}$ as:

'We are open to assaults more than ever. Under such circumstances, the victory of the proletariat cannot survive with power in a few countries, but it can only feel secure if it reaches to victory in all or most of the countries in the world. This means that capitalist encirclement must be replaced by socialist encirclement.'(Stalin,1952)

As a matter of fact, in his famous 'Election Speech' on February 8, 1946 just prior to the Supreme Soviet elections, Joseph Stalin stressed the inevitability of wars between capitalist and communist systems. In this speech, he made no distinction between capitalist regimes and the Nazi Germany. Such an indifferent manner in his speech was interpreted as the declaration of war against the West. This speech made an alarming effect on the Western powers impelling them to take urgent security measures. In the eyes of Stalin, it was no other

\footnotetext{
${ }^{4}$ Problems of Leninism
} 
thing than stressing once again the deterministic view of Marxist-Leninist doctrine as natural evolution of the history that he had written in the Voprosy Leninizma. Yet it was sufficient in terms of putting the Soviet strategic doctrine under a huge burden. Following the Soviet Second World victory, Europe had an appealing impact on the Soviet regime in terms acquiring both ideological and strategic advantage for the future of her well-being. It was quite clear that that Soviet Union geographically had more vulnerability of being encircled as compared to the United States. Such a vast land territory made Soviet Russia vulnerable to be 'contained'. This has also consolidated the self-esteem of the Soviet state that felt extremely obsessed with being encircled by the capitalist West. Indeed, as stated above the Soviet regime had undertaken an immense burden in terms of the pursuing a coherent strategic doctrine whose success would mostly depend on the European geography. Confronted with a 'capitalist encirclement' would Moscow be able to find the optimum between defence and the offense?

Secondly, there is no doubt that the impact of the Second World War trauma was significant in the formation of the constants of the Soviet regime. It would soon turn out to be one of the building blocks of the Soviet strategic identity and culture. The trauma of the Operation Barbarossa on 22 June 1941 played a considerable role in the formation of the Soviet strategic culture as well as Soviet strategic doctrine. In order not to experience the trauma of 1941 once again, the Soviet regime regarded it essential to make military mobilization one of the core elements of its military doctrine. Thus, the traumatic impact of the German invasion turned into a constant factor that the Soviet regime could never hold apart from her strategic identity and culture. While talking to Milovan Djilas, one of the leaders of the Partisan Movement in April 1945, Stalin was sure of the fact that Germany would rise again as a great power within 12-15 years' time (Djilas,1962). In this conversation, Stalin also talked about the inevitability of a new world war within 10-15 years' time following the end of the Second World War (Djilas,1962).

On the other hand, victory at the end of the Second World War signified a new strategic as well as ideological channel for the Soviet regime. For sure, the victory in the Second World War has gained a doctrinarian self-esteem to the Soviet Union. The transition to rapid economic take-off has strengthened the doctrinal belief that the socialist system was strong in defeating 'imperialism' (Lee and Starr,1986). And this caused the Soviet regime a direct encounter with the capitalist European geography. Yet Joseph Stalin regarded this an opportunity towards the achievement of the 'inevitable truth' in the evolution of the world history. The Second World War was regarded by the Stalinist regime as the beginning of the clashes which Vladimir Ilyich Lenin had previously predicted. After all, the Soviet regime had emerged one of the power centres in the world following 4 years of struggle of survival. Thus, in the eyes of the Stalinist regime there was no reason why they must not adhere to the evolution of human history predicted by Marxism-Leninism. Under such a biblical guidance, the arising question was how would deterministic dynamics would be revitalized given the tough strategic conditions of the European political geography following the Second World War.

\section{IV.ON WHOSE SIDE IS THE STRATEGY?}


As stressed above if a strategic doctrine is to accomplish its goals, it has to find appropriate solutions concerning the geography picked as the target. The Soviet strategic doctrine had to find 'compact solutions' to the European geography in terms of reaching a correct optimum. For a doctrinaire state like the Soviet Union, there had to exist an enduring ideological cohesiveness in order to make a sound and stable strategy possible. In other words, strategy could by no means change or modify the ideological boundaries and barriers drawn by the Marxist-Leninist ideology. Yet on the other hand, this would by no means change the fact that Soviet Union as the revisionist side had to convert this ideological cohesiveness into a coherent and sustainable strategy. Since the post-Second World Soviet strategy was formed upon the legacy of the Second World War, undertaking such a legacy would mean drawing a restrictive boundary on the Soviet security policy and strategies.

The basic goal of the Soviet strategic doctrine was based on holding the strategic upper hand by seeking to form a counter force against the 'capitalist encirclement' by the West. The equivalent of this doctrinal aspect of Soviet strategic approach was 'correlation of forces. This was a concept much different from the balance of power concept that the European diplomacy has been familiar for centuries. It has a broader meaning than the concept of balance of power, because it included political, economic and intangible elements besides the military ones. The concept correlation of forces was the expression of the Soviet Union's concern to keep her strategic advantage over the capitalistic forces rather than making equilibrium a priority (Aspaturian,1980). The Soviet regime regarded her ideological extension towards Eastern and Central Europe like a strategic asset for both assaulting 'capitalist encirclement' and preventing any possible assault against its own existence. The Eastern Bloc was to function as strategic leverage for the interests of the Soviet state that the Marxist-Leninist regime would use against Western European states. Quite related to this, the fact that Moscow was conditioned to creating a pro-Soviet influence in the Eastern Europe well before forming the 'Iron Curtain' and it was something that the legacy of the armed struggle against Hitler Germany had imposed on the Stalinist regime. It was no other thing than forming a security zone in the aftermath of the Second World War. In the formulation of this zone, Poland had been picked as one of the preeminent actors to undertake a strategic role. At the Yalta Conference, Stalin had demanded a 'friendly' Poland arguing that Poland has functioned as a corridor throughout the ages for the invasion of Russia.

But Germany's position was much more crucial than Poland's. Both ideological and strategic task would be designated to Germany in a complementary sense, because seizing the ideological upper hand in Europe would definitely mean seizing the strategical upper hand. In such a role, Berlin would play a crucial role in this ideological and strategic formulation. If Berlin could be brought under the influence of Marxist-Leninist ideology that could well mean the Soviet ideological domination in the entire Germany. As a price of the suffering of the Second World War, the Soviet Union would seize the strategic superiority in the Eastern and Central Europe which would give the Marxist-Leninist regime the potential to narrow the scope of manoeuvre to the Western powers' detriment. Molotov had stressed this fact by confessing 'We were simply on the offensive. They became angry at as, of course, but we had to consolidate what we conquered.' (Zubok,2007)

Yet Moscow was unaware of the fact that having entered into the post-Second World War international order as an actor with doctrinal identity would bring her unbearable strategic 
costs. One of the most striking deficiencies of such an ideological conditioning was definitely leaving no buffer zone in terms of minimizing her strategic traps. This would continuously keep Moscow obsessed with 'capitalist encirclement.'

It was possible to observe the first signs of this conditioning in Moscow's policy towards Turkey. As a result, Moscow's pushing Turkey into the orbit of the Western alliance was by no means a unexpected move which I believe that the first major strategic mistake that Moscow made in the post-War era. Soviet Foreign Minister Molotov called the Turkish Ambassador Selim Sarper to his office and informed him that Moscow would not renew the Friendship Treaty of 1925 signed for 20 years. This would be the beginning of distrust of Ankara towards Moscow which pushed her to seek a security alliance with the West. Turkey's becoming a NATO member in 1925 certainly impelled Moscow to pursue much more adventurous steps in her Cold War policy given this magnitude of 'containment'. That was certainly the beginning of the process that Moscow by herself began to narrow the area of manoeuvre for the sake of the ideological reasoning. During his vacation in Varna Khrushchev said he would demonstrate to the United States how it was to feel surrounded by missiles (Naftali and Fursenko, 1997).

Certainly, Europe would be the very geography that Moscow would base both her main strategic defence and offense. The European geography was the geography that she will maintain the strategic rivalry with her main antagonist, the United States. The basic problem in the accomplishment of the Soviet strategy was that Europe was both the geography that Soviet Union had historically security concerns and it considered seizing strategic advantages against capitalistic powers. Therefore, Europe was a geography which Moscow had to integrate the defensive and offensive moves in her strategy. Yet European strategic terrain would demonstrate any such strategic coherence which would meet the strategic requirements of the Soviet regime.

In this first phase of strategic approach, we observe a rigid ideological concentration by Moscow on Europe. Implementing the dictates of Marxist-Leninist doctrine was a question of mission for Moscow not to allow any 'capitalist takeover' of Europe. The Soviet strategic doctrine demonstrated its positioning very well with the Moscow's rejection of the Marshall Plan since Marshall Plan was regarded by Moscow as a submission to the capitalist takeover of the Eastern European economies. Therefore, the taking of the entire Eastern Europe under Moscow's control would be a strong bulwark against 'imperialistic powers.' Yet, Stalin behaved so brutally in this concern. The Prague Coup on March 1948 accelerated the approval of the European Recovery Aid in the US Congress. Yet the most striking impact of the Prague Coup was stepping up the pressures on the part of Western Europe paving the way for the foundation of NATO as a Transatlantic security pact. Besides, the negative impact of the Berlin Blockade of 1948 on Moscow was confirmed by the formation of the Western bloc against Moscow. The Western power strengthened their presence in Germany and this accelerated the process of the formation of the Western military alliance against the Soviet Union. Even Western communist parties distanced away from Moscow which could be a strategic asset in the long run. This cost of this was the emergence of West German militarization as a new security challenge on behalf of Soviet strategy towards Europe. The emergence of NATO as an actor would render the critical line between defence and offense vague than ever on behalf of Moscow. It would almost nullify any chance of flexibility. The 
Korean War has worsened the image of the Soviet Union paving the way for the acceptance of NSC-68 by the Truman Administration. The Truman administration believed that the Western world had been exposed to a war waged by the 'international communism'.

Moscow had an unshakable belief that communism will replace capitalism the 'the inevitable forces of history.' Yet the Soviet strategy towards 'the imperialists' did not follow a stable path and it was exposed to interpretations and 'revisionisms' in this strategic adaptation quest. This was the second phase of the Soviet strategy against the West. This second phase began with Nikita Khrushchev's historic address at the XX. Soviet Communist Party Congress in 1956 which he uttered peaceful coexistence. This new era marked its distinctiveness by the adoption of new priorities in reaching the goals of Marxism-Leninism. And definitely it would be the Khrushchev era which would be determinative in the fate of Soviet strategy. Nikita Khrushchev's main task would be to facilitate and speed up this process by focusing on economic goals. Khrushchev's ideological interpretation of the Marxist-Leninist doctrine would dramatically affect the course of Soviet strategy in the Cold War. Khrushchev's rejection of the inevitability of wars between the capitalist and the communist world signified a new course in terms of foreseeing Soviet ideological supremacy against the West. This has gained an economic notion to Soviet strategy which was definitely lacking during the Stalinist era. It stressed the fact that it would not be realistic for any Soviet grand strategy be held exempt from an economic notion. Nevertheless, this was also an overt invitation to the deepening of 'big picture' question within the Soviet grand strategy: How to optimize economic goals with the arms race against the United States?

The Khrushchev era in the Soviet Cold War grand strategy was directed towards reprioritizing the strategic goals of the Soviet regime. But it was a naked truth that it would be the Khrushchev era that Soviet Union would be much more vulnerable to falling prey to the temptations of strategic traps. The strategic terrain was extremely tough for Moscow in terms of harmonizing her geopolitical and ideological priorities towards the Containment policy. In so far as the Containment policy exerted an immense pressure on Soviet geopolitics with Eisenhower-Dulles foreign policy, that would impel Nikita Khrushchev to find responses intending to paralyze the strategic steps of the Eisenhower administration.

Yet, regardless of the fact that Nikita Khrushchev demonized Stalin in his XX. Party Congress Speech, he had inherited a Cold War legacy from Stalin that she would never dare to deny or reverse it. Having inherited Stalin's Germany policy, in so far as he felt rising pressure of the West Germany over the Eastern Germany, his security concerns soared. Khrushchev was aware of the fact that Soviet Union was facing another 'German Question'. There is no doubt that the 'German Question' would be the most enigmatic strategic trap in terms of making a correct assessment on the well-being of the Soviet grand strategy. The main cause of this fact was that Germany was attributed to the role of playing both defence and offense positions. Soviet Union initiated her strategic approach towards Europe with serious strategic gaps, because Soviet stretch towards the Western Europe had left no buffer zone in terms of heeding the critical defence-offence optimum. Just as to stress this point Khrushchev had said:

'We must take the initiative and restore order in Hungary. If we leave Hungary, that will encourage the Americans, English and the French, the imperialists. They will perceive it as weakness and go on the offensive ...Our party won't understand our 
behaviour. To Egypt they (the imperialists) will add Hungary. We have no other choice. We cannot possibly permit it, either as Communists or internationalists, or as the Soviet state. We would have capitalists on the frontier of the Soviet Union.' (Taubman,2003) Over this, Khrushchev told Tito his concerns how he would be condemned if Hungary is 'lost.' An opinion would be prevalent within the CPSU that when Stalin had been in power everybody had obeyed him and when a leader came to power condemning Stalin, Soviet Union began to be exposed to defeats as in the example of Hungary(Taubman,2003).This demonstrated its deep impact as soon as the Soviet ideology and strategy became extremely obsessed with Germany. Such a strategic culture of narrowing the Soviet strategic alternatives encouraged Soviet foreign and security policies into adventurous actions. It rendered Khrushchev's over concentration on the German question almost an inevitability making the Soviet regime extremely vulnerable to strategic gaps and traps. Regardless of the fact that a Marxist-Leninist revolution could be achieved in the east part of Germany, East Germany and especially Berlin has turned into a strategic burden that involved urgent solutions. The income gap between the West and the East was widening and due to flux of immigration towards West, East Germany was losing its work force.

The Khrushchev era was so crucial for the future of the Soviet Cold War policies since it was with the beginning of the Khrushchev era that the strategic gaps of the Soviet Union began to come to the surface and could be more dramatically felt. Moscow was confronted with the toughest geopolitical challenge from Germany from where she was attacked in 1941 in her quest to achieve this harmony. The concern to clarify the future of Germany within time has turned into serious security challenges that involved urgent solutions in the eyes of Moscow. This was nothing more than deepening of Soviet strategic troubles. In finding the correct strategic harmony, the Soviet leaders were facing the counter-productive effects of the Soviet strategic culture and it was no other thing than the traumatic effect of 1941. The main concern or even obsession of the Soviet leaders has always been not to 'sacrifice' Germany whose price had been paid by the blood of the Soviet soldiers. Thus, Germany would never rescue itself from being the preeminent strategic asset of the Marxist-Leninist Soviet state. Indeed, Germany would be the crucial strategic challenge that will determine the position of Soviet Union in Europe.

But there is no doubt that the insistence of Soviet Union on the ideological capture of Germany has drifted the Soviet Union into a strict red line position allowing no strategic buffer zone. The rejection of the Marshall Plan by Moscow had already demonstrated its significance in exposing East Germany to the appeal of the West German economic dynamism. This was sufficient to create an alarming effect over the security perceptions of Nikita Khrushchev. This was also the very factor that put the Soviet bloc into a strategic vulnerability and strategic traps. It has pushed Moscow to adopt extremely aggressive tactics against the appealing effect of West Germany and its economy. Nothing would exhaust Soviet strategic behaviour than the appealing effect of Germany as Berlin being the epicentre of it. Moscow would never forestall Berlin's turning into being a strategic burden from a strategic asset for the Soviet interests in European theatre.

The sectorial division of Berlin caused strategic deficiencies on behalf of Moscow's MarxistLeninist doctrine. This has ushered in the question whether which side really held the strategic control. In the eyes of Moscow, the existence of West Berlin was as a threat for the well-being 
of East Germany. Well beyond its ideology the way of life in West Berlin was a threat against the way of life in Moscow as well as in East Berlin. Yet a target geography picked as a strategic asset for Moscow turned into a strategic trap was by no means possible to avoid. The Soviet position in Eastern and Central Europe was drifted into a position that East-West Germany relations captivated the Soviet regime's strategic positioning and behaviour. There is no doubt that the doctrinal view of the Soviet Union impelled her getting obsessed with the obsession between ideological encirclement. This has rendered the Soviet regime tying its own security to the future of Germany. Being in the position of a revisionist power did not prevent Moscow being exposed to the diplomatic attacks of Bonn. In this regard the West German Foreign Minister Carstens' visit to Moscow in 1965 became a setback for Moscow. Besides, West Germany had already established trade missions in Bulgaria, Romania, Hungary and Poland. Moscow had a great desire to complete the non-proliferation treaty negotiations process so that Germany does not acquire any nuclear capability. It was alarming enough for Moscow that the diplomatic initiative in Eastern Europe had passed to West Germany. Moscow had indeed converted West Germany into a diplomatic powerhouse that she would be compelled to make counter moves.

As an inevitable outcome of these, the Berlin issue that Stalin never yielded to step back turned into a strategic trap. It was not possible to reverse the strategic position of the Soviet Union in Europe in the name of peaceful coexistence. That would totally shake the strategic position of Soviet Union in Europe. As a consequence of this, his policy served no other than maintaining Stalin's policies more aggressively. Berlin continued to be at the heart of being the most significant nuisance on behalf of Soviet diplomacy. This has made its imminent effect of deepening the prioritization question on behalf of the Soviet Union. That is why it was no surprise on the part of Nikita Khrushchev to stress the West German Chancellor Konrad Adenauer his primary goals as raising the welfare standard of the Soviet society, reaching qualitative equality in arms race and eliminating the threat from People's Republic of China during his visit to Moscow (Maier,1975). In order to match Americans in economy, he badly needed breakthrough in Soviet nuclear technology (Fursenko and Naftali,2006). He was in favour of cutting 1-1.2 million soldiers for the sake of prioritizing his economic goals (Fursenko and Naftali,2006). There was no doubt that would be an invitation to the strengthening of reactionist forces within the party.

The Politburo meeting that Khrushchev was sacked from the post of Secretary General, would reveal how the inner logic of the Marxist-Leninist Soviet regime would never allow the emergence of new strategic alternatives. Deputy Prime Minister and former KGB Chief Alexander Shelepin was against the philosophy underlying peaceful coexistence (Fursenko and Naftali,2006). He also denounced his visit to Egypt since he was sacrificing Soviet dignity for the sake of seeking alliances with anti-Communist Nasser (Fursenko and Naftali,2006). Nasser had launched a "witch hunt" campaign against the communists in 1959 he regarded them no other than Western imperialists (Laqueur,1972).

Now that the area of manoeuvre was narrowed as a result of the intensification of the Containment policy during Eisenhower-Dulles era, Nikita Khrushchev had to refer to coercive diplomacy more than ever as a counter response. Yet using of strategic arms as a leverage would be a blowback for Moscow in the Cuban Missile Crisis. In the absence of any precedence, Nikita Khrushchev could not risk escalating the conflict. But it was obvious from 
beginning that the 'Anadyr Operation' whose goal was to place Soviet missiles into Cuba would lead to a disaster on behalf of both Khrushchev and the Soviet foreign policy. Khrushchev could not estimate correctly that no American administration would allow missiles on a communist island in the Caribbean. In the meeting that Khrushchev was sacked from the leadership, KGB Chief Shelepin told Khrushchev that Operation Anadyr had been a risky enterprise in which Khrushchev had juggled with people's fates. It was a morbid competition with America. (Fursenko and Naftali,2006) The rulers of Soviet regime were inclined to be impressed by the appeal of the communist revolutions in the developing world. The strategic position that the Soviet Union had kept put herself into such an impasse that it would be much easier for her to fall prey to the temptations of strategic traps. As a matter of fact, Cuban Missile Crisis was nothing more than the manifest of a deeper problem in terms of the accomplishment of a sound Soviet Cold War grand strategy. The impasse of that Nikita Khrushchev got into was indeed a manifest of deep strategic problems inherent within Soviet regime. Just to indicate this fact Anastas Mikoyan, Khrushchev's right-hand man, had once confessed to the U.S. Secretary of State Dean Rusk:

'You Americans must understand what Cuba means for us old Bolsheviks. We have been waiting all our lives waiting for a country to go to communist without the Red Army, and it happened in Cuba. It makes us feel like boys again.' (Rusk,1991)

Similarly, in the eyes of Khrushchev, the East German regime was the first worker and peasant state whose price had been paid by the lives of millions of Soviet citizens (Zubok,1993).

The succeeding Brezhnev era would be so crucial in determining the fate of Soviet strategy towards Europe regardless of the fact that Brezhnev era was not the final period of the Soviet Union. For, no matter how much Nikita Khrushchev was humiliated at the historical Politburo meeting on 14 October 1964 in which he was sacked, it would deepen the incoherence on behalf of Soviet strategy towards Europe. Despite Khrushchev's fall, Soviet foreign policy would never return to the Stalin-Molotov line again. For Brezhnev there was no way to any tension regarding Berlin since he felt the pressure of Peking upon Moscow. Brezhnev said to Khrushchev his reforms were opposed to Lenin's principles. This was a very strong sign that Soviet Union was beginning to evolve towards being a status quo power. In this sense, the Brezhnev era was a manifest that Soviet Union could no longer maintain the position of a revisionist power and had no other choice than consenting to a status quo position in her challenge against the West. This is how the Soviet military interventions during the Brezhnev era had to be evaluated correctly.

Certainly, one of the reasons why the Brezhnev regime felt compelled to make a military intervention to Czechoslovakia in 1968 following the Prague Spring was precisely the fact that the fall of Czechoslovakia would cause unbearable strategic consequences in terms of the survival of the Soviet regime. Without any doubt the invasion of Czechoslovakia caused the Soviet Union to fall into a strategic trap that she would never rescue itself. The fact that the East Bloc had been always open to political unrest was for sure the weakest side within the very strategic harmony that the Soviet regime sought to find. Since Czechoslovakia was the neighbouring country to West Germany and Austria, that would definitely signify a strategic setback for the Warsaw Pact. Brezhnev needed to stress this point just because of this very reason that it was by no means possible that Czechoslovakia would break up from the Soviet Union (Zubok,2007). Brezhnev even told to the Soviet Ambassador to Prague that events 
even would lead to his own fall if revisionist movements in Czechoslovakia do not cease. Brezhnev was correct to be concerned as Czechoslovakia was a neighbouring country with West Germany and Austria, it would definitely mean, a geopolitical weakness for the Warsaw Pact she leaves the Eastern the pact. Secondly, Leonid Brezhnev while explaining why they felt obliged to make a military intervention Czechoslovakia intervention in 1968 was talking about the price they had paid during the Second World War. Brezhnev stressed that against the pains of the Soviet people, and the military and civil losses they had to guarantee their security in Europe for the price of a divided Europe (Zdenek,1980:239-240).

Adenauer just like George Kennan prophetically believed that the Soviet Union would decay slowly instead of rapid transformation (Maier,1975). The most significant strategic trap for Moscow was that the Iron Curtain turned into a political geography that the Western bloc benefited strategically. Soviet Union could not respond the strategic traps deriving from the vast geography it had 'overstretched'. In other words, it has remained quite exposed to the outbreak of 'fires to be extinguished' in its surroundings. The use of force and armed interventions erupting dissident movements in East Germany, Poland, Hungary and Czechoslovakia fed long term reactionist behaviour rather than consolidating the ideological coherence within the Soviet bloc. The Eastern Bloc once the strongest geopolitical offense of the Soviet regime turned into her greatest strategic wound.

Even if Leonid Brezhnev might have satisfied his legitimacy quest by signing Helsinki Final Act, this was no other thing than submitting the Soviet regime to the process of decay. By the Helsinki Final act, all the parties would commit themselves to respect the sovereignty and territorial integrity of all signatory states. This would definitely reduce any Soviet military intervention towards any East Bloc country to a minimum. On the other hand, by signing the Helsinki Final Act, the Soviets were putting the East Bloc countries under the influence of Western influence by paving the way of broader technical and economic cooperation with the Western Europe. And with the bosting effect of Helsinki Final Act, Vaclav Havel published together with the opposition intellectuals the famous "Charta 77" declaration by the arrest of members of the rock band 'Plastic People of the Universe' on January 61977 . The 'Charta 77' declaration was accusing the Czechoslovakian regime of not abiding by the Helsinki Final Act. On behalf of gaining legitimacy to her presence in the Eastern Europe, the Brezhnev regime was narrowing its area of strategic manoeuvre. The ideological element played a crucial role in the overwhelming of the strategic notion, because Brezhnev regime was seeking a victory while the thirtieth anniversary of the Second World War was approaching. On the other hand, an incident in Bulgaria during the follow-up meetings of Conference on Security and Cooperation Europe (CSCE) the time was running against the Soviet regime. During this follow-up meeting, the NGO Ecoglasnost demonstrated to protest the pollution at the Black Sea. This demonstration of the Ecoglasnost was under high surveillance of $D S^{*}$ which did not hesitate to take action in order to suppress it. Yet this crackdown of $D S$ was taking place in front of Western diplomats who came to Sofia to participate in the conference. Especially the brutal beating of a woman led to protests of all of members of CSCE to which Moscow also had joined.

\footnotetext{
${ }^{*}$ Darzhavna Sigurnost (State Security)
} 
It was remarkable that the area of manoeuvre was narrowing in the 'East Bloc' on the part of Moscow. Moscow's negotiation proposals were triggering other long-drawn-out European issues to be 'reawakened'. The Western Bloc's precondition for CSCE negotiations to start was the beginning of immediate negotiations on the resolution of the Berlin question. When the negotiations concluded with an agreement, this signified another strategic trap for Moscow. By the signature of Quadripartite Agreement in 1971, Moscow agreed that West Germany could represent West Berlin and issue passports for Western Berliners. The Quadripartite Agreement was definitely a 'Trojan Horse' for Moscow. Brandt had believed that East German regime and the other East Bloc regimes could never be stabilized as long as people could travel freely (Smyser,1999:259).

One of the neglected realities of the Marxist-Leninist Soviet regime was her geopolitical vulnerability which would be sufficient enough to distort the required strategic harmony. Like other hegemons in the past overstretching has become a reality that the Soviet Union would never imagine to shun, because Afghanistan cannot just be seen as a neighbouring country that could upset the integrity and ideological well-being of the Soviet Union. Hafizullah Amin as the leader of the Khalq faction toppled Taraki, leader of the rival Parcham faction and began to approach to the Carter administration, Brezhnev regime's response to this was the decision to liquidate him. Afghanistan as a neighbouring country to the Soviet republics of Turkmenistan and Azerbaijan had become extremely fragile towards the regional influences following the Iranian Islamic revolution in 1979. If Soviet Union was to be surrounded by Islamic regimes, it would be the United States that would benefit from it. The Islamic uprising on 15 March 1979 in Herat in which Afghan officers had also participated had alarming effect on the Brezhnev regime. Afghanistan was the first state which officially recognized and made the first international treaty with the Bolshevik regime in 1921. Gorbachev admits the burden of Afghan war in the collapse of the Soviet Union. In his address to CPSU's Twenty-Seventh Congress, Gorbachev called the Afghan war as a bleeding wound (Reuveny and Prakash,1999). There is no doubt that the Afghan war has aggravated the disharmony of the constant factors within the Soviet regime. As soon as the invasion has begun, anti-Soviet and anti-government rally was organized in Kabul with the participation of three hundred thousand people. The Afghan War became a perfect strategic trap for the Soviet regime. The Afghan invasion has turned into a jihadist war in the eyes of the resistances forces with the mujahedeen forces seeing no other limit than defeating the atheist Soviet regime. And the magnitude of the jihadist war grew with the increasing participation of mujahedeen from other Islamic countries. The effort to take the countryside under control intensified Soviet military operations which fed the anti-Soviet sentiments in the countryside and as a result of this has pushed the countryside towards the mujahedeen groups. (FremontBarnes,2012)Uzbek or Tajik soldiers deployed against the Mujahedeen resistance made the counterproductive effect of increasing the reaction towards these people of USSR by the Afghan population(Feifer,2009).As Feifer argues since the war was prolonging, the mujahedeen groups were becoming much more experienced and were convinced that time was working in favour of them(Feifer,2009). Besides the Zia Ul-Haq regime in Pakistan knew how to manipulate the funds given by the Reagan administration in favour of prolonging of the war. Even in the clandestine aid to mujahedeen factions, cheap AK-47 rifles purchased from the East Bloc was distributed to them. 
In quest for finding strategic harmony, Soviet Union's problems deepened with the intensifying arms race. It is possible to observe one crucial strategic weakness of Moscow in the on-going arms races. For sure, making European geography a strategic terrain was an overt invitation to an arms race. Overconcentration to arms race with the United States would never allow Soviet Union to prioritize its strategic goals. The last Secretary General of the Soviet Communist Party Mikhail Gorbachev states in his memoirs that the share military expenses in the budget was 40 per cent instead of 16 per cent (Gorbachev,1997). And 20 million roubles of 25 roubles allocated to scientific researches were assigned to military aims (Gorbachev, 1997).

Moscow as a security doctrine has felt compelled to respond to Washington in the arms race. In fact, Europe was not a convenient asset for the Soviet Union to pursue an effective strategy. George Arbatov, the head of 'America Canada Institute' admits that deploying SS20 was a big mistake. It has not only cost the Soviet state millions of rubbles but it united NATO as well. Following this decision NATO adopted much more aggressive stance against the Soviet Union (Arbatov,1992). Mikhail Gorbachev confirms this reality in his memoirs. The decision to deploy SS-20s to Eastern Europe caused grave consequences in terms of the interests of Soviet security. As a reaction to the deployment of SS-20, NATO adopted counter-measures by deploying Pershing II missiles which were able to reach even to most densely populated parts of USSR(Gorbachev,1997). Gorbachev indicates also how West German Chancellor Helmut Schmidt had warned him that the deployment of SS-20s would compel the West to take counter-measures (Gorbachev,1997).

Given all these facts, it is not hard to understand that the Soviet ideology could not demonstrate the required flexibility in terms of acquiring a full strategic identity. One of the strategic impasses of the Soviet administrations was definitely falling into the trap of 'friendly-hostile' nations dichotomy. Such a dictate imposed a huge ideological burden on their strategic manoeuvring ability. There could be no better ideological reasoning than Marxist-Leninist ideology in terms of restraining the effectiveness and the efficiency of the strategic thinking in terms of creating area of manoeuvre. Thus, the Soviet security and military strategy would never rescue itself from the rigid restraints of the Marxist-Leninist ideology.

While the Cold War was about the end, the Soviet Union demonstrated all the evidence of not being able to harmonize her geopolitical realities with her future ideological well-being. In the emerging strategic landscape, the Soviet Union fell into the position of occupying force in Czechoslovakia or in Afghanistan for the sake of Soviet geopolitics as well as Soviet regime. Having been the main liberator of the Eastern Europe in the Second World war, it was the Soviet Union that fell into the position of occupier and the brutal hegemon. Its strategic consequences were worse than the military or clandestine interventions of the United States in the developing world, because the interventions of the United States had not targeted the capitalist camp while the interventions of the Soviet Union were upon the communist camp. The split in the communist camp became a burden on the Soviet regime that she could hardly bear. Suffering under the burden of the interventions of 1953 East Germany, 1956 Hungary and 1968 Czechoslovakia, the Soviets had already lost their will power and credibility to make a new intervention. In this context, it will be quite useful to heed to the observations of American ambassador to Moscow Jack Matlock during Reagan and Bush administrations. 
'Although Soviet Union still possessed enormous military power, she no longer had the political will to apply it in Eastern Europe. And the experience in Afghanistan had proved costly in terms of public opinion, and Gorbachev had just managed to extricate the country from that failed adventure. He could not precipitate military confrontation in the heart of Europe without abandoning his entire reform program and probably losing his job as well.' (Matlock, 1995)

Since the driving force was defeating the capitalist, forces, there could be no alternative to the seizure of Eastern Europe or insistence on the integrity of post-war Germany. The cause underlying this rationality was that the Soviet state had to care about its ideological wellbeing as a national security concern. There is no doubt that we find the temptation of European geopolitics playing the preeminent strategic weakness on behalf of Moscow. It would be by no means possible for any Soviet strategy to keep itself away from the appeal of the European geopolitics. In other words, Europe was no such a geography that the Soviet Union would keep away itself from its temptations.

\section{V.CONCLUSION}

Stalin had regarded the Eastern Bloc as its main strategic asset. Europe was such a political geography that Stalin believed Soviet Union could strike the most fatal blow to. This policy served nothing more than tying both its strategic and ideological well-being to Eastern Europe. The Soviet ideological concentration into the Eastern Europe lest Eastern Europe was not used as a corridor following her Second War victory had formed an undeniable organic link between Soviet Union and Eastern Europe that Soviet Union would not imagine her existence without the Eastern Bloc. Yet, Moscow's rigid conditioning of an organic link between Soviet Union and the East Bloc was sufficient to distort its inner harmony and this was also a major factor in her losing the Cold War.

The Soviet strategic experience marked its place in history of strategic thought with its stress of disharmony between ideology and strategy. It indicated how a strategy under the yoke of an ideology may well impel a hegemonic power falling into strategic traps. The underlying cause of this fact was that the pre-eminence of ideological goals on the part of the Soviet regime involved much more sophisticated strategic adaptation capability which was extremely hard to achieve. Yet, her inner philosophic logic remained incoherent and weak in terms of finding correct the strategic responses faced with the dynamics of the Cold War.

That is why, 'bicycle example' was fit to explain Soviet strategic experience. It had to move in order to stand. The Marxist-Leninist ideology was not sensitive in terms of granting the strategic thinking its real value, because the Soviet strategic culture would not allow such a harmony before everything. It has made extremely harder Moscow's actions to be measured with strategic values. The big picture of the Soviet Union was well above that any strategic thought could bear. The fact of the well-being of Soviet ideology was measured with so many components waiting to be harmonized was not something that could be adapted to the strategic thought. Soviet Union turned into a status quo power in the pursuit of getting the maximum share in the status quo order rather than maintaining her revisionist power position. She could not escape the temptations of the geography that she has 'overstretched. The Soviet Union had entered strategic game beginning in the post-Second World with the goal of revitalizing the 'inevitable forces' of the world history. Yet Moscow could by no means forestall those 'inevitable forces' to turning against herself. 'The German dualism' that she 
could never bring any solution to turned into a strategic burden that would reverse the inevitable forces of the history. While intending to speed up the 'inevitable forces of history', Soviet Union fell behind the 'inevitable forces of history' and even be succumbed by them. 'The correlation of forces' was quite counterproductive in missing the big picture. Strategic thought was under the dictate of the goals of communist ideology instead of ideology under the dictate of strategic thought. Soviet Union lost the big picture against the capitalist West, because strategy signified something for Moscow in so far as it met the requirements of the Soviet ideological coherence. Moscow had every reason to remain indifferent to the inner coherence of the strategy.

Thus, the greatest strategic failure of the Soviet Union in her strategic approach towards Europe was not to able to find the optimum between ideological and strategic stretch. There was no red line drawn in terms of determining the restraints of the Soviet Cold War policy. This has rendered Soviet Union extremely exposed to the pressure of strategic traps. Europe which once referred a strategic superiority has turned into a strategic trap for the Soviet regime. The Soviets both failed to seize a stronghold on the European geography and got into the process of strategic set back against 'capitalist forces. The strategic positioning of the Soviet Union demonstrated an obvious dissimilarity with the strategic positioning of the traditional hegemonic powers. She was not able to escape the burden that geopolitics of the Soviet Union has imposed herself as a Eurasian power. Briefly this can be seen as the strategic story of the Soviet Union as a Eurasian hegemon. Given all those negative effects of its strategic approach towards Europe, it is obvious to see that in fact the Soviet ideology was no fit for the accomplishment of a grand strategy. Its ideology was hindering the prioritization of certain strategic goals. Marxist-Leninist monopoly over the delicate requirements of Cold War foreign policy has gradually narrowed the scope of strategic thinking in the Cold War game.

\section{REFERENCES}

Arbatov, Georgi(1992).The system:An insider's life in Soviet politics, New York, N.Y.:Random House.

Aspaturian, V. V. (1980). Soviet global power and the correlation of forces, Problems of Communism,May/June,pp.1-18.

Black,J.(2008).Great Military Leaders and Their Campaigns,London:Thames and Hudson.

Djilas,M.(1962).Conversations with Stalin, New York,N.Y:Harcourt Brace.

Feifer, G. (2009). The Great Gamble: The Soviet war in Afghanistan.New York,N.Y.:Harper.

Fremont-Barnes,G.(2012).The Soviet-Afghan war 1979-1989,Peterborough:Osprey.

Freedman,L.(2013).Strategy:A history, New York,N.Y:Oxford University Press.

Fursenko, A. and Naftali,T.(2006). Khrushcevs's cold war:The inside story of American adversary, New York,N.Y.,Norton.

Fursenko,A. and Naftali, T.(1997).One hell of a gamble:Khruschev, Castro, Kennedy,and the Cuban missile crisis 1958-1964,London:John Murray.

Gorbachev, M. (1997). Memoirs, New York,N.Y. Bantam Books. 
Hart,L. B.H.(1967).Strategy,London,Meridian.

Heather,P,(2005).The fall of the Roman empire:A new history. London: MacMillan, p.443.

Henderson, B. W. (1969). Five Roman emperors, New York,N.Y.: Barnes and Noble.

Kennedy,P.(1989). The rise and the fall of the great powers.New York,N.Y.:Vintage Books.

Kerr,J. G.(2015).Road to Helsinki,Bloomington,IN:iUniverse.

Laqueur, W. (1972). The Struggle for the Midde East: The Soviet Union and the Middle East 1958-1970, Middlesex: Penguin Books.

Luttwak,E.N.(1983).The Grand Strategy of the Soviet Union. New York,N.Y.:St. Martin's Press.

Lynch,M.(2010).Osprey guide to Chinese civil war,Osprey.

Maier,H.(ed)(1975).Konrad Adenauer:Seine Deutschland und aussenpolitik 19451963,Münich:Deutscher Taschenbuch Verlag.

Maresca,J.J.(1985).To Helsinki:The Conference on security and cooperation in Europe 19731975,Durham,N.C.:Duke University Press.

Matlock, J, F.Jr.(1995). Autopsy on an empire: The American ambassador's account of the collapse of the Soviet Union. New York,N.Y.: Random House.

Mlynar, Z. (1980).Night frost in Prague,New York,N.Y.:Karz Publishers.

Rafael R. and Prakash,A.(1999). The Afghanistan War and the Breakdown of the Soviet Union, Review of International Studies, Vol 25,No 4,pp.693-708.

Rusk, D. (1991). As I saw It: A secretary of state's memoirs.London:Tauris.

Smyser,W.R.(1999).From Yalta to Berlin:The cold war struggle over Germany,London:MacMillan.

Snyder,J.(1991).Myths of empire :Domestic politics and international ambition, Ithaca, N.Y.: Cornell University Press.

Stalin,J.(1952)Voprosu Leninizma.Moskva: Gosudarstvennoe izdatel'stvo politicheskoŭ literatury.

Taubman,William(2003).Khruschev:The man and his era,New York,N.Y.:Norton.

Taylor,J.(2009).The Generalissimo:Chiang Kai-Shek and the struggle for modern China,Cambridge,MA.:Harvard University Press.

Zubok,V. M., Pleshakov, C.(1996).Inside the Kremlin's cold war:From Stalin to Khruschev,Cambridge,MA.:Harvard University Press.

William T. L. Starr R.F. (1962). Soviet military policy since world war II. Stanford,CA:Hoover Institution Press.

Zubok,V.M.(2007).The Soviet Union in the cold war from Stalin to Gorbachev,New Delhi:Dev.

Zubok, V.M., Khruschev and the Berlin Crisis(1958-1962(1993).Cold War Internationl History Project,Working Paper 6, Washington, D.C.:Woodrow Wilson International History Project. 